\title{
Restricted gene flow between Holothuria scabra (Echinodermata: Holothuroidea) populations along the north-east coast of Australia and the Solomon Islands
}

\author{
S. Uthicke ${ }^{1, *}$, J. A. H. Benzie ${ }^{1,2}$ \\ ${ }^{1}$ Australian Institute of Marine Science, PMB No 3, Townsville, Queensland 4810, Australia \\ ${ }^{2}$ Centre for Marine and Coastal Studies, University of New South Wales, Sydney, New South Wales 2052, Australia
}

\begin{abstract}
To describe patterns of gene flow for the fished holothurian species Holothuria scabra 17 to 141 individuals were collected from 8 populations from north-east Australia, the Torres Strait, and the Solomon Islands. Samples were investigated by allozyme electrophoresis of 7 polymorphic loci. Cluster analyses using Rogers' genetic distance identified 3 distinct groups of populations from the north-east coast of Australia, representing samples from the 3 regions Hervey Bay, Upstart Bay and Torres Strait. Populations in the latter region were closely connected to those from the Solomon Islands. $F$-statistics indicated restrictions in gene flow (average genetic variation between populations, $\left.F_{\mathrm{ST}}=0.088\right)$. Hierarchical analyses revealed that $94.7 \%$ of the variation was within sampling locations. Approximately $77 \%$ of the variance among populations was due to differences between regions, and $23 \%$ within regions (most of the latter caused by differences between the 2 Solomon Island populations). Mantel's tests indicated that a high proportion of the variation in genetic distances along the north-east coast of Australia was explained by isolation by distance (Mantel's normalised $Z=0.88)$. This proportion reduced when the Solomon Islands were included $(Z=0.65)$. The detection of separate stocks along the north-east coast of Australia is an important finding that has significant consequences for the development of sustainable management plans for this species. Low dispersal may significantly reduce recovery of overfished areas if no local refugia are provided.
\end{abstract}

KEY WORDS: Connectivity $\cdot$ Holothurians $\cdot$ Invertebrate fisheries

\section{INTRODUCTION}

Fishing for several aspidochirotide holothurian species (bêche-de-mer) is an important source of income for many developing countries throughout the IndoPacific region. However, due to the current high demand in China, over-harvesting can now be considered a global phenomenon in developing countries (examples in Conand 1997, Conand \& Jaquemet 2000). Recent data showed that over-exploitation can also be

\footnotetext{
*E-mail: s.uthicke@aims.gov.au
}

a problem in developed countries such as Australia, with relatively well managed coral reef ecosystems (Uthicke \& Benzie 2000a).

Holothuria scabra ('sandfish') is one of the most important species for the tropical bêche-de-mer fishery (Conand 1989a). Despite the commercial importance of $H$. scabra, information on the biology and ecology of this species is sparse. Such information is urgently needed for management of the fishery and to understand the impact of the fishery on the ecosystem. $H$. scabra is one of the few tropical aspidochirotide species which prefers coastal areas to coral reefs (Conand $1989 b, 1993)$. It is often found in seagrass beds, and 
seagrass plays an important function in triggering larval settlement (Mercier et al. 2000). The sandfish burrows into the sediment for part of the day (Wiedemeyer 1993, James et al. 1994, Mercier et al. 1999), and fishing of this species usually takes place by walking at low tides. Sexual reproduction via broadcast spawning occurs in the warm months (December to February) in the southern hemisphere (Harriott 1980, Conand 1989b, 1993). The planktotrophic larvae of this species spend 10 to $14 \mathrm{~d}$ in the water column before reaching late pentactula stage and subsequent settlement (Battaglene et al. 1999, Mercier et al. 1999). There is, therefore, potential for larval dispersal between populations.

It has been established that the 2 colour varieties observed for Holothuria scabra are conspecific and that shallow and deep populations in 1 area of Australia were genetically undistinguishable (Uthicke \& Benzie 1999). The latter finding is consistent with the view that juveniles settle in shallow seagrass beds and then migrate to deeper areas during their life span (Vail 1989, James et al. 1994). Although their function in seagrass ecosystems has not been studied, holothurians have important functions in bioturbation and nutrient recycling in coral reef ecosystems (Uthicke 1999, 2001). Therefore, one may assume that apart from direct effects of fishing on population densities, a reduction in holothurian densities will have secondary ecological effects.

Information on the connectivity of exploited populations is an important pre-requisite for managers to decide on which scale (e.g. local or regional) a fished stock should be managed. Furthermore, such information allows an assessment of the potential geographical range of ecological consequences of over-fishing on the population level and to advise on the usefulness of protective measures such as marine protected areas.

Allozyme markers have proved to be a useful tool for describing gene flow and have been used to describe connectivity of echinoderm populations in the Great Barrier Reef (GBR) (Benzie \& Stoddard 1992, Williams \& Benzie 1993, Uthicke \& Benzie 2000b). These studies focussed on reef species and described high rates of gene flow along the entire length of the GBR, consistent with the general perception that long larval duration leads to high connectivity between populations. Genetic differences between populations were found in 2 holothurian species on the GBR (Uthicke et al. 1998, 1999), but this was attributed to the effects of asexual reproduction, which occurs in these species in addition to sexual reproduction. Holothuria scabra is not known to reproduce asexually, and it is not a reef species, but inhabits coastal areas. Therefore, connectivity between populations may differ from that of other echinoderm species investigated on the north- east coast of Australia. The aim of the present study was to investigate geneflow between populations separated by different geographic scales ( 20 to $2000 \mathrm{~km}$ ), along the north-east coast of Australia, Torres Strait and the Solomon Islands, to provide information on connectivity to assist management and add to fundamental knowledge on the biology of this ecologically and economically important species.

\section{MATERIAL AND METHODS}

Sampling strategy. Two shallow populations of Holothuria scabra were sampled in the area of Hervey Bay (Urangan: $152^{\circ} 54^{\prime} \mathrm{E}, 2^{\circ} 18^{\prime} \mathrm{S}$; Tin Can Bay: $153^{\circ}$ $01^{\prime}$ E, $25^{\circ} 49^{\prime} \mathrm{S}$ ) in south Queensland during June 1998 (Fig. 1). Individuals from a deeper population in Hervey Bay (18 to $20 \mathrm{~m}$ ) were obtained during 3 trawl shots (approximate position: $153^{\circ} 04^{\prime} \mathrm{E}, 24^{\circ} 59^{\prime} \mathrm{S}$ ) using commercial prawn-trawling equipment. One intertidal population was sampled ca. $800 \mathrm{~km}$ north (Upstart Bay: $147^{\circ} 42^{\prime} \mathrm{E}, 19^{\circ} 50^{\prime} \mathrm{S}$ ). (Data from these samples were used in a previous study investigating the relationship between 2 colour morphs and the gene flow between deep and shallow populations: Uthicke \& Benzie 1999.) During August 1999, samples were obtained from 2 reefs in the Torres Strait at the northern end of the GBR (Warrior Reef: $143^{\circ} 01^{\prime} \mathrm{E}, 09^{\circ} 45^{\prime} \mathrm{S}$; Dungeness Reef: $\left.142^{\circ} 57^{\prime} \mathrm{E}, 09^{\circ} 55^{\prime} \mathrm{S}\right)$. Two locations in the Solomon Islands, Kohinggo Island $\left(157^{\circ} 06^{\prime} \mathrm{E}, 08^{\circ} 09^{\prime} \mathrm{S}\right.$ : hereafter called Solomon Island A) and Kolombangarra Island (156 $59^{\prime} \mathrm{E}, 08^{\circ} 04^{\prime} \mathrm{S}$ : Solomon Island B), were sampled in December 1999. Because the individuals in the Upstart Bay population sampled in 1998 were exceptionally small, this population was re-sampled in May 2000 to investigate whether gene frequencies and the small size of individuals were stable over time.

Samples from intertidal populations were taken during low tides by walking on the mud flats. During these periods, holothurians in shallow tide pools, usually with at least a sparse seagrass cover, migrate to the surface of the sediment. Since large areas had to be covered to obtain sufficient individuals, no effort was made to obtain subsamples within each of the populations. The length of all individuals was recorded to the nearest centimetre. A subsample of the gut lining (cleaned from sediments) was snap frozen in liquid nitrogen for later analyses.

Allozyme electrophoresis. Approximately $250 \mathrm{mg}$ of frozen gut tissue was homogenised in the same volume of Tris $\mathrm{HCl}$ buffer (100 mM Tris adjusted to $\mathrm{pH} 8.0$ with $\mathrm{HCl})$ prior to electrophoresis. Electrophoresis of all enzymes was performed on $12 \%$ horizontal starch gels. Seven polymorphic enzyme loci were surveyed: phosphoglucomutase (E.C. 5.4.2.2, $P G M^{*}$ ), hexokinase 
(E.C. 2.7.1.1, HK*) and glucose-6-phosphate isomerase (E.C. 5.3.1.9, GPI*) as described in Uthicke \& Benzie (1999), were analysed on TEC7.9 gels (electrode buffer 135 mM Tris, $32 \mathrm{mM}$ citric acid, 4 mM Na${ }_{2}$ EDTA, pH 7.87; gel buffer $8.5 \mathrm{mM}$ Tris, $2 \mathrm{mM}$ citric acid, $0.27 \mathrm{mM} \mathrm{Na}_{2}$ EDTA, pH 7.87, electrophoresis for $16 \mathrm{~h}$ at $90 \mathrm{~V})$. Malate dehydrogenase (E.C. 1.1.1.37, $M D H^{*}$ ) and peptidases (E.C. $3.4 .11 / 13)$ were analysed on TG8.4 gels (electrode and gel buffer $25 \mathrm{mM}$ Tris, $192 \mathrm{mM}$ glycine, pH 8.4, $230 \mathrm{~V}$ for $16 \mathrm{~h}$ ). Different substrates allowed detection of activity in several peptidase loci. The results for these are reported as Peptidase Locus 1 (PEP-1*, migration distance 6.5 to $7.5 \mathrm{~cm}$, visible on leucyl-glycyl-glycyl, LGG), PEP-2* (visible on leucyl-proline, travel distance 2.5 to $3.5 \mathrm{~cm}$ ) and $P E P-3^{*}$ (visible on LGG and valyl-leucine, migration distance 1 to $2 \mathrm{~cm}$ ). Full details of staining and electrophoresis methods are given in Ballment et al. (1997).

Statistical analyses. Basic analyses of genetic variability were carried out using programs in the BIOSYS-1 package (Swofford \& Selander 1981). F-statistics, cluster analyses and tests of conformation to Hardy-Weinberg expectations were performed using the TFPGA package (Miller pers. comm. 1997, computer software distributed by author). Weir \& Cockerham's (1984) methods for calculating Wright's F-statistics with corrections for unequal sample size were used. Total genetic variation $\left(F_{\text {IT }}\right)$ was partitioned into that occurring within populations $\left(F_{\mathrm{IS}}\right)$ and that occurring between populations $\left(F_{\mathrm{ST}}\right)$. The significance of $F_{\mathrm{IS}}$ and $F_{\mathrm{ST}}$ values was tested using the $\chi^{2}$ statistic as described in Waples (1987). In addition, the $95 \%$ confidence intervals for the average $F_{\mathrm{ST}}$ and $F_{\mathrm{IS}}$ values were calculated by bootstrapping across loci. Hierarchical F-statistics (Wright 1978) were calculated to partition variation into that occurring within sampling locations, between sampling locations within regions, and between regions (Hervey Bay, Torres Strait and Solomon Islands). The contribution of these variances to the total variance was calculated after Preziosi \& Fairbairn (1992). The latter analysis excluded the Upstart Bay sample, because only 1 population had been obtained from that region.

One parameter that had previously proved to be a reliable estimator for the contribution of asexual reproduction to each population was calculated to test whether this mode of reproduction occurs in Holothuria scabra, although it has not been reported previously. The maximum input of sexual reproduction in each population was estimated by calculating the maximum number of sexually produced individuals $\left(\mathrm{N}^{*}\right)$

and dividing this by the sample size (Johnson \& Threlfall 1987). The calculation of this parameter is described in detail in Uthicke et al. (1998).

Deviations from Hardy-Weinberg equilibrium for each locus at each reef were tested by an exact-test, using the conventional Monte Carlo method with the default settings in TFPGA. Significance values were corrected for multiple simultaneous tests with a sequential Bonferroni correction described by Hochberg (1988).

To test for evidence of isolation by distance, Mantel's (1967) tests were performed on transformed $(\log +1)$ geographic distance $(\mathrm{km})$ and Rogers' genetic distances (Rogers 1972). The significance of Mantel's normalised $Z$ was tested by 10000 random permutations using NTSYS-PC software (Rohlf 1990).

\section{RESULTS}

With the exception of $M D H^{*}$, all loci investigated for Holothuria scabra were polymorphic in all populations, and most alleles (exceptions are $P G M^{80}, H K^{90}, G P I^{113,90}$ ) were found in all populations (Table 1).

Genotype frequencies were not significantly different from those expected under Hardy-Weinberg equilibrium (exact-test, $\mathrm{p}>0.05$ after corrections for multiple tests), with 1 exception. The $P G M^{*}$ locus showed significant heterozygote deficits $(\mathrm{p}=0.000)$ for only 1 population. 
Table 1. Holothuria scabra. Allele frequencies at 7 loci in 8 geographical populations. Numbers in parentheses: sample size at each locus

\begin{tabular}{|c|c|c|c|c|c|c|c|c|c|}
\hline \multirow[t]{2}{*}{ Locus } & \multirow{2}{*}{ Urangan } & \multirow{2}{*}{$\begin{array}{c}\text { Tin Can } \\
\text { Bay }\end{array}$} & \multirow{2}{*}{$\begin{array}{l}\text { Trawl } \\
\text { shots }\end{array}$} & \multicolumn{2}{|c|}{ Upstart Bay } & \multirow{2}{*}{$\begin{array}{c}\text { Warrior } \\
\text { Reef }\end{array}$} & \multirow{2}{*}{$\begin{array}{l}\text { Dungeness } \\
\text { Reef }\end{array}$} & \multicolumn{2}{|c|}{ Solomon Islands } \\
\hline & & & & 1998 & 2000 & & & A & $\mathrm{B}$ \\
\hline$P G M^{*}$ & $(100)$ & (16) & $(136)$ & (49) & $(54)$ & (41) & (30) & $(30)$ & $(23)$ \\
\hline 100 & 0.625 & 0.656 & 0.629 & 0.592 & 0.593 & 0.646 & 0.583 & 0.383 & 0.674 \\
\hline 94 & 0.080 & 0.094 & 0.110 & 0.092 & 0.093 & 0.073 & 0.083 & 0.15 & 0.022 \\
\hline 90 & 0.230 & 0.219 & 0.213 & 0.255 & 0.250 & 0.195 & 0.183 & 0.100 & 0.174 \\
\hline 86 & 0.045 & 0.031 & 0.037 & 0.061 & 0.065 & 0.085 & 0.150 & 0.300 & 0.130 \\
\hline 80 & 0.020 & 0.000 & 0.011 & 0.000 & 0.000 & 0.000 & 0.000 & 0.067 & 0.000 \\
\hline$H K^{*}$ & $(100)$ & (17) & $(141)$ & (49) & (54) & $(42)$ & (30) & (30) & (23) \\
\hline 100 & 0.870 & 0.912 & 0.890 & 0.908 & 0.889 & 0.762 & 0.783 & 0.467 & 0.652 \\
\hline 94 & 0.130 & 0.088 & 0.110 & 0.092 & 0.111 & 0.226 & 0.200 & 0.533 & 0.348 \\
\hline 90 & 0.000 & 0.000 & 0.000 & 0.000 & 0.000 & 0.012 & 0.017 & 0.000 & 0.000 \\
\hline$G P I^{*}$ & $(100)$ & $(17)$ & $(141)$ & $(50)$ & $(54)$ & $(42)$ & (30) & $(30)$ & (23) \\
\hline 113 & 0.000 & 0.000 & 0.018 & 0.000 & 0.019 & 0.060 & 0.067 & 0.05 & 0.022 \\
\hline 100 & 1.000 & 1.000 & 0.982 & 0.900 & 0.898 & 0.929 & 0.917 & 0.950 & 0.870 \\
\hline 90 & 0.000 & 0.000 & 0.000 & 0.100 & 0.083 & 0.012 & 0.017 & 0.000 & 0.109 \\
\hline$M D H^{*}$ & $(100)$ & $(17)$ & $(141)$ & $(50)$ & $(54)$ & $(42)$ & (30) & $(30)$ & $(23)$ \\
\hline 100 & 0.990 & 0.941 & 0.993 & 1.000 & 1.000 & 1.000 & 1.000 & 1.000 & 1.000 \\
\hline 91 & 0.010 & 0.059 & 0.007 & 0.000 & 0.000 & 0.000 & 0.000 & 0.000 & 0.000 \\
\hline$P E P-1^{*}$ & $(87)$ & (14) & $(108)$ & (39) & (54) & $(42)$ & (29) & (30) & (23) \\
\hline 106 & 0.488 & 0.464 & 0.616 & 0.269 & 0.352 & 0.357 & 0.431 & 0.433 & 0.283 \\
\hline 100 & 0.512 & 0.536 & 0.384 & 0.731 & 0.648 & 0.643 & 0.569 & 0.567 & 0.717 \\
\hline$P E P-2^{*}$ & $(100)$ & (17) & $(140)$ & (50) & (54) & $(42)$ & (29) & $(30)$ & $(23)$ \\
\hline 100 & 0.835 & 0.853 & 0.854 & 0.9 & 0.898 & 0.548 & 0.552 & 0.617 & 0.543 \\
\hline 94 & 0.165 & 0.147 & 0.146 & 0.1 & 0.102 & 0.452 & 0.448 & 0.383 & 0.457 \\
\hline$P E P-3^{*}$ & $(100)$ & (17) & $(141)$ & $(50)$ & (54) & $(42)$ & (30) & (30) & (23) \\
\hline 100 & 0.920 & 0.794 & 0.926 & 0.440 & 0.472 & 0.631 & 0.733 & 0.700 & 0.630 \\
\hline 95 & 0.080 & 0.206 & 0.074 & 0.560 & 0.528 & 0.369 & 0.267 & 0.300 & 0.370 \\
\hline
\end{tabular}

Table 2. Holothuria scabra. Summary statistics and parameters describing genetic variability at 7 loci in 8 geographical populations. Standard errors are given in parentheses where appropriate, standard deviations are given for length measurements. Calculations of $\mathrm{N}_{\mathrm{i}}, \mathrm{N}_{\mathrm{go}}$, and $\mathrm{N}^{*}$ are only based on individuals for which all loci could be scored

\begin{tabular}{|c|c|c|c|c|c|c|c|c|c|}
\hline Station & $\begin{array}{l}\text { Mean } \\
\text { sample } \\
\text { size }\end{array}$ & $\begin{array}{l}\text { Mean no. } \\
\text { of alleles } \\
\text { per locus }\end{array}$ & $\begin{array}{l}\% \text { of loci } \\
\text { poly- } \\
\text { morphic }\end{array}$ & $\begin{array}{l}\text { Mean hete } \\
\text { Observed } \\
\quad\left(\mathrm{H}_{\mathrm{o}}\right)\end{array}$ & $\begin{array}{l}\text { rozygosity } \\
\text { Expected } \\
\quad\left(\mathrm{H}_{\mathrm{e}}\right)\end{array}$ & $\begin{array}{l}\text { No. of } \\
\text { Ind. } \\
\left(\mathrm{N}_{\mathrm{i}}\right)\end{array}$ & $\begin{array}{c}\text { No. of } \\
\text { genotypes } \\
\text { observed }\left(\mathrm{N}_{\mathrm{go}}\right)\end{array}$ & $\mathrm{N}^{*} / \mathrm{N}_{\mathrm{i}}$ & $\begin{array}{c}\text { Average } \\
\text { length } \\
\text { (cm) }\end{array}$ \\
\hline Urangan & $98.1(1.9)$ & $2.4(0.5)$ & 85.7 & $\begin{array}{c}0.209 \\
(0.066)\end{array}$ & $\begin{array}{c}0.247 \\
(0.082)\end{array}$ & 87 & 54 & 1 & $17.8(2.5)$ \\
\hline Tin Can Bay & $16.4(0.4)$ & $2.1(0.3)$ & 85.7 & $\begin{array}{c}0.264 \\
(0.082)\end{array}$ & $\begin{array}{c}0.274 \\
(0.076)\end{array}$ & 14 & 13 & 1 & $14.4(1.8)$ \\
\hline Trawl shots & $135.4(4.6)$ & $2.4(0.4)$ & 100.0 & $\begin{array}{c}0.216 \\
(0.069)\end{array}$ & $\begin{array}{c}0.237 \\
(0.078)\end{array}$ & 105 & 58 & 1 & $26.9(4.1)$ \\
\hline Upstart Bay 1998 & $48.1(1.5)$ & $2.1(0.3)$ & 85.7 & $\begin{array}{c}0.253 \\
(0.071)\end{array}$ & $\begin{array}{c}0.287 \\
(0.079)\end{array}$ & 39 & 31 & 1 & $9.8(1.5)$ \\
\hline Upstart Bay 2000 & $54.0(0.0)$ & $2.3(0.4)$ & 85.7 & $\begin{array}{c}0.294 \\
(0.075)\end{array}$ & $\begin{array}{c}0.302 \\
(0.080)\end{array}$ & 54 & 43 & 1 & $9.1(2.6)$ \\
\hline Warrior Reef & $41.9(0.1)$ & $2.4(0.4)$ & 85.7 & $\begin{array}{c}0.291 \\
(0.065)\end{array}$ & $\begin{array}{c}0.355 \\
(0.078)\end{array}$ & 41 & 39 & 1 & $19.7(3.0)$ \\
\hline Dungeness Reef & $29.7(0.2)$ & $2.4(0.4)$ & 85.7 & $\begin{array}{c}0.333 \\
(0.076)\end{array}$ & $\begin{array}{c}0.360 \\
(0.081)\end{array}$ & 29 & 28 & 1 & $19.4(3.0)$ \\
\hline Solomon Island A & $30(0.0)$ & $2.3(0.5)$ & 85.7 & $\begin{array}{c}0.352 \\
(0.099)\end{array}$ & $\begin{array}{c}0.393 \\
(0.097)\end{array}$ & 30 & 28 & 1 & $20.0(2.4)$ \\
\hline Solomon Island B & $23.0(0.0)$ & $2.3(0.4)$ & 85.7 & $\begin{array}{c}0.385 \\
(0.082)\end{array}$ & $\begin{array}{c}0.373 \\
(0.072)\end{array}$ & 23 & 22 & 1 & $21.6(3.3)$ \\
\hline
\end{tabular}


Fig. 2. Holothuria scabra. Dendrogram illustrating genetic relationships among 9 samples from the Queensland coast, Torres Strait and the Solomon Islands (SI A, SIB) using UPGMA cluster algorithm and Rogers' (1972) genetic distance. Values above the nodes represent bootstrap values obtained by 1000 permutations. The cophenetic correlation of the analyses was 0.86

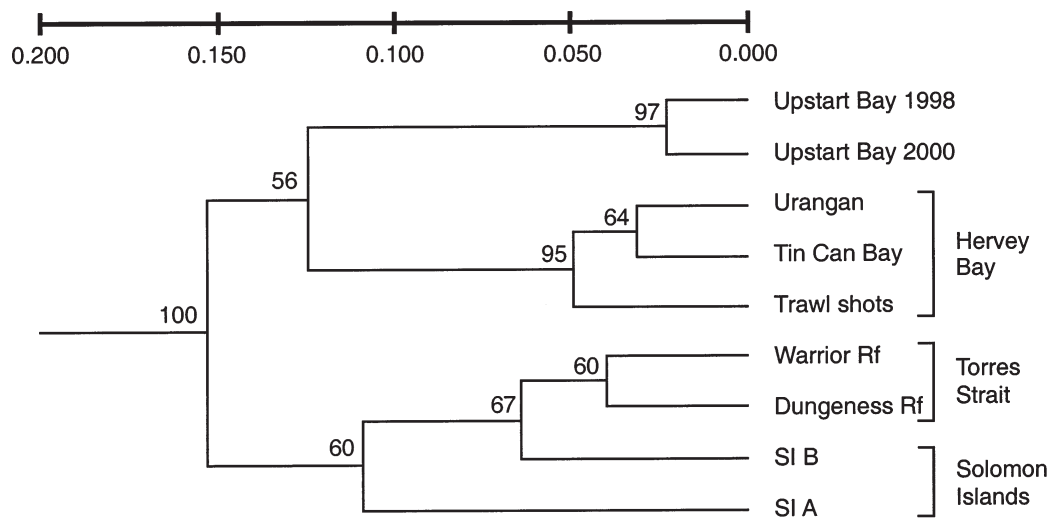

There was no apparent difference in genetic variability (expressed as mean number of alleles per locus, \% polymorphic loci or heterozygosity) among the populations investigated (Table 2). The number of genotypes observed was distinctly below the number of individuals sampled in populations with large sample size (Urangan and trawl samples). However, calculation of the upper $95 \%$ confidence estimate for the number of sexually produced individuals $\left(\mathrm{N}^{*}\right)$ indicates that these genotypes were likely to be repeatedly produced by sexual reproduction, and the ratio of $\mathrm{N}^{*} / \mathrm{N}_{\mathrm{i}}$ was 1 for each population (Table 2).

The average length of Holothuria scabra varied at different locations (Table 2). Largest individuals (mean $26.9 \mathrm{~cm}$ ) were sampled in the deep population in Hervey Bay ('Trawl shots'), and the average length of most other populations ranged between 14 and $22 \mathrm{~cm}$. Individuals sampled in Upstart Bay in 1998 and June 2000 were small $(\sim 9 \mathrm{~cm})$ at both sampling times.

Cluster analyses using Rogers' (1972) genetic distance clearly grouped sites by geographical region (Fig. 2). The 3 main clusters corresponded to (1) samples from Upstart Bay, (2) samples from the Hervey Bay area, and (3) samples from the Torres Strait and the Solomon Islands. One sample location from the lat- ter islands appeared relatively distinct from the other population from the Solomon Islands and the Torres Strait samples. An exact test revealed no significant differences $\left(\chi^{2}=4.89, \mathrm{df}=14, \mathrm{p}=0.981\right)$ between samples from Upstart Bay in 1998 and 2000. Therefore, those samples were pooled for subsequent analyses.

Differences between samples from the 2 locations in the Solomon Islands were significant (exact-test, Table 3). In most other cases, the results from the exacttest confirmed the clusters obtained with UPGMA (Fig. 2). Several comparisons involving Tin Can Bay were not significant, which is likely to have been caused by the small sample size for that population. Table 3 also lists pairwise genetic distances expressed as Nei's (1978) unbiased genetic distances, for comparison with other studies.

There was only a weak, but significant (Mantel's normalised $Z=0.66, \mathrm{p}=0.0004$ ) relationship between geographic distances and Rogers' (1972) genetic distance (Fig. 3). When samples from the Solomon Islands were excluded from this analysis, a larger portion of the variation in the genetic distances was explained by geographic separation $(Z=0.88, \mathrm{p}=0.003)$.

Significant $F_{\mathrm{ST}}$ values were detected for all loci (Table 4 ). The confidence interval for the overall $F_{\mathrm{ST}}$

Table 3. Holothuria scabra. Nei's (1978) unbiased genetic distances (above diagonal) and p-values of the exact tests for population differentiation (below diagonal) for each pair of populations. Bold print indicates significant $(\alpha=0.05)$ population differentiation, after sequential Bonferroni corrections for 28 multiple simultaneous tests

\begin{tabular}{|lcccccccc|}
\hline & 1 & 2 & 3 & 4 & 5 & 6 & 7 \\
\hline 1 Urangan & - & 0.0000 & 0.0019 & 0.0496 & 0.0346 & 0.0200 & 0.0616 & 0.0487 \\
2 Tin Can Bay & 0.6620 & - & 0.0017 & 0.0238 & 0.0229 & 0.0145 & 0.0626 & 0.0385 \\
3 Trawl & 0.2780 & 0.2553 & - & 0.0619 & 0.0483 & 0.0292 & 0.0733 & 0.0680 \\
4 Upstart Bay & $\mathbf{0 . 0 0 0 0}$ & $\mathbf{0 . 0 0 0 5}$ & $\mathbf{0 . 0 0 0 0}$ & - & 0.0336 & 0.0436 & 0.0840 & 0.0413 \\
5 Warrior Reef & $\mathbf{0 . 0 0 0 0}$ & 0.0083 & $\mathbf{0 . 0 0 0 0}$ & $\mathbf{0 . 0 0 0 0}$ & - & 0.0000 & 0.0311 & 0.0000 \\
6 Dungeness Reef & $\mathbf{0 . 0 0 0 0}$ & 0.0610 & $\mathbf{0 . 0 0 0 0}$ & $\mathbf{0 . 0 0 0 0}$ & 0.9621 & - & 0.0245 & 0.0034 \\
7 Solomon Island A & $\mathbf{0 . 0 0 0 0}$ & $\mathbf{0 . 0 0 0 0}$ & $\mathbf{0 . 0 0 0 0}$ & $\mathbf{0 . 0 0 0 0}$ & $\mathbf{0 . 0 0 0 2}$ & 0.0160 & - & 0.0222 \\
8 Solomon Island B & $\mathbf{0 . 0 0 0 0}$ & $\mathbf{0 . 0 0 0 0}$ & $\mathbf{0 . 0 0 0 0}$ & $\mathbf{0 . 0 0 0 0}$ & 0.5429 & 0.2894 & $\mathbf{0 . 0 0 2 5}$ & - \\
\hline
\end{tabular}


Table 4. Holothuria scabra. F-statistics for 8 populations. * Significant at $\alpha=0.05_{i}{ }^{* *}$ significant at $\alpha=0.01$ (after sequential Bonferroni corrections); ns: not significant. Lower part of the table shows results from the hierarchical $F$-statistics. $F_{\text {IT }}$ : total genetic variation; $F_{\mathrm{ST}}$ : variation between populations; $F_{\mathrm{IS}}$ : variation within populations

\begin{tabular}{|c|c|c|c|}
\hline Locus & $F_{\text {IT }}$ & $F_{\mathrm{ST}}$ & $F_{\text {IS }}$ \\
\hline PGM* & 0.1711 & $0.0121^{*}$ & $0.1610^{* *}$ \\
\hline$H K^{*}$ & 0.1602 & $0.1015^{* *}$ & $0.0654^{\mathrm{ns}}$ \\
\hline$G P I^{*}$ & 0.0622 & $0.0446^{* *}$ & $0.0184^{\mathrm{ns}}$ \\
\hline$M D H^{*}$ & -0.0023 & $0.0151^{*}$ & $0.0177^{\mathrm{ns}}$ \\
\hline$P E P-1^{*}$ & 0.1185 & $0.0556^{* *}$ & $0.0666^{\mathrm{ns}}$ \\
\hline$P E P-2^{*}$ & 0.1750 & $0.1167^{* *}$ & $0.0660^{\mathrm{ns}}$ \\
\hline$P E P-3^{*}$ & 0.2938 & $0.2180^{* *}$ & $0.0969^{\mathrm{ns}}$ \\
\hline Average & 0.1744 & 0.0877 & 0.0950 \\
\hline Upper $95 \%$ CI & 0.2290 & 0.1542 & 0.1315 \\
\hline Lower $95 \%$ CI & 0.1277 & 0.0362 & 0.0580 \\
\hline \multicolumn{4}{|c|}{ Hierarchical F-statistics: } \\
\hline & & Variance & $F_{\mathrm{ST}}$ \\
\hline \multicolumn{2}{|c|}{ Location within region } & 0.027 & 0.012 \\
\hline \multicolumn{2}{|c|}{ Location within total } & 0.124 & 0.053 \\
\hline \multicolumn{2}{|c|}{ Region within total } & 0.097 & 0.041 \\
\hline
\end{tabular}

value does not encompass zero, indicating significant restrictions in gene flow between populations. Hierarchical F-statistics showed that $94.7 \%$ of the variance was within sampling locations (Table 4). Of the remaining variance, $77.4 \%$ were caused by differences between regions and only $22.6 \%$ were due to differences between locations within regions. Further analysis showed that the latter variance component was mainly caused by the differences between the 2 Solomon Island populations.

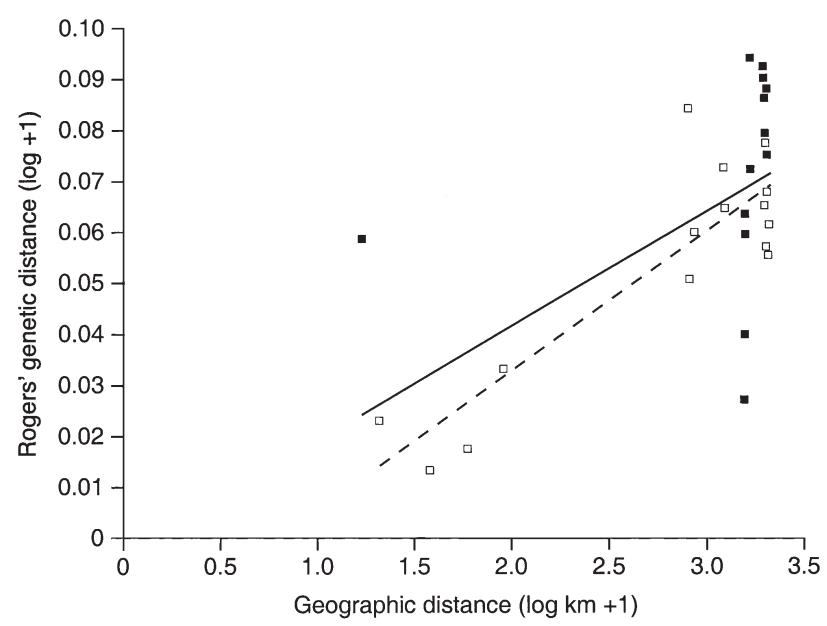

Fig. 3. Holothuria scabra. Relationship between Rogers' (1972) genetic distance and geographic distance including all sample locations $(\square, \mathbf{\square}$, continuous line) and excluding the Solomon Islands $(\square$, dashed line $)$
Table 5. Estimates of the expected number of migrants per generation $\left(\mathrm{N}_{\mathrm{e}} \mathrm{m}\right.$, calculated assuming a stepping-stone model) between populations derived from pairwise $F_{\mathrm{ST}}$ values. (A) Pairwise estimates between populations within regions; (B) populations within regions were pooled to derive estimates for gene flow between regions

\begin{tabular}{|lc|}
\hline & $\mathrm{N}_{\mathrm{e}} \mathrm{m}$ \\
\hline (A) Populations within regions & \\
Urangan vs Tin Can Bay & $\infty$ \\
Urangan vs Trawl shots & 196.8 \\
Tin Can Bay vs Trawl shots & 138.3 \\
Warrior Reef vs Dungeness & $\infty$ \\
Solomon Island A vs B & 34.1 \\
(B) Populations between regions & \\
Hervey Bay vs Upstart Bay & 7.6 \\
Hervey Bay vs Torres Strait & 12.3 \\
Hervey Bay vs Solomon Islands & 7.3 \\
Upstart Bay vs Torres Strait & 14.4 \\
Upstart Bay vs Solomon Islands & 9.5 \\
Torres Strait vs Solomon Islands & 63.7 \\
& \\
\hline
\end{tabular}

Given that the data were consistent with the presence of isolation by distance, the number of expected migrants $\left(\mathrm{N}_{\mathrm{e}} \mathrm{m}\right)$ between populations were derived from pairwise $F_{\mathrm{ST}}$ values assuming a stepping-stone model (Slatkin 1993). Calculations were performed as described in Benzie \& Williams (1997), assuming a mutation rate of $\mu=10^{-7}$ (Nei 1987: p. 30 to 38). Large numbers of migrants were observed between populations within areas (Table 5), with the smallest values being observed between the 2 sample locations at the Solomon Islands. Estimates of $\mathrm{N}_{\mathrm{e}} \mathrm{m}$ between regions were generally more than 1 order of magnitude lower, with highest migration rates observed between the Torres Strait and the Solomon Islands regions. However, all estimates involving Torres Strait yielded relatively high migration rates compared to other pairwise comparisons.

\section{DISCUSSION}

This study investigated gene flow in Holothuria scabra populations with a view to increasing knowledge on this commercially important species and assisting management. Allozyme analyses have identified that $H$. scabra populations along the north-east coast of Australia can be grouped into at least 3 genetically distinct stocks: (1) southern populations from the Hervey Bay area, (2) one population from the central coast, and (3) populations from Torres Strait. The latter region is closely related to samples from the Solomon Islands.

Although several studies on reef fishes (Doherty et al. 1995), giant clams and foraminiferans (Benzie 1994), 
and crown-of-thorns populations on the GBR (Benzie \& Stoddart 1992) reported some significant $F_{\text {ST }}$ values, these were about 1 order of magnitude less than those reported here. Several other studies on invertebrates of the GBR (Benzie \& Williams 1992, Williams \& Benzie 1993, Uthicke \& Benzie 2000b) did not detect any significant population differentiation between populations separated by distances of up to $1500 \mathrm{~km}$. The only published $F_{\mathrm{ST}}$ values of a similar order of magnitude to, or higher than, those observed here are for species which are viviparous (Ayre \& Dufty 1994) or which have asexual reproduction (Burnett et al. 1995, Uthicke et al. 1998, 1999). With 1 exception, all loci in all populations were in Hardy-Weinberg equilibrium. The contribution of the Wahlund effect (this may reduce heterozygosity due to population subdivision) to the heterozygote deficits at that locus was calculated to be approximately $2 \%$, suggesting that the source of these deficits is some variation in breeding success among particular genotypes at that site. The maximum number of sexually produced individuals in each population equals the sample size (i.e. $N^{*} / N_{i}=1$ ). Together with the overall low deviations from Hardy-Weinberg equilibrium, this confirmed the general perception that asexual reproduction is not a feature of the biology of Holothuria scabra. Therefore, it can be concluded that differences in gene frequencies do not result from differential asexual reproduction. Although there are differences in the degree of differentiation among populations for different loci, the fact that all contribute to population differentiation suggests that patterns of spatial differentiation in H. scabra is not the result of selection either, but of restrictions in gene flow among populations.

Estimates of gene flow are correlated to dispersal ability across a large variety of taxa from terrestrial, freshwater and marine environments (Bohonak 1999). The time span of planktonic larval development is often considered as a factor limiting dispersal in the marine environment (e.g. Hedgecock 1986, Doherty et al. 1995). However, larval development in Holothuria scabra takes at least 14 d (Battaglene et al. 1999, Mercier et al. 2000), a time span well within the range of that for other invertebrates which lack or show only marginal population differentiation (see previous paragraph). The main difference to the studies cited above is that the present study investigated a species which is mainly distributed nearshore, not on the GBR proper. With the exception of the samples from Torres Strait, samples were obtained from muddy intertidal seagrass beds directly at the coast. One possible reason for restricted larval dispersal may therefore be a different current regime near the coast compared to the GBR proper. On mid and outer shelf reefs of the GBR, the main current flow is generally south-east- ward during summer, the spawning period for most invertebrates on the reef. This results in a large potential for larvae to disperse over the GBR (Williams et al. 1984). Williams et al. suggested that the net drift in summer in nearshore areas will be more restricted due to periodic reversal of water movements in that area. Furthermore, gene flow between populations along coastlines may be restricted by physical and hydrological barriers, or by lack of prey for larvae (Hedgecock 1986). An offshore movement of the East Australian Current was one of the likely reasons for the population subdivision of Actinia tenebrosa on the temperate east coast of Australia (Ayre et al. 1991). Similarly, shelf water is transported seaward in an area north of our Hervey Bay samples (Burrage et al. 1996) which may restrict longshore movement of larvae produced in this area towards the north. It is possible that similar hydrological features exist along the north-east coast of Australia, restricting gene flow between other coastal populations investigated here.

The GBR consists of nearly 3000 single reefs, and distances between a reef and its nearest neighbour rarely exceed $15 \mathrm{~km}$. Therefore, even if larvae were not dispersed over long distances, the reefs can act as stepping stones, allowing populations to mix over a small number of generations. This appears not to be the case for coastal species such as Holothuria scabra. Finding the populations sampled proved time-consuming. Although it is certain that not all populations on the north-east coast were sampled, it appears that populations of $H$. scabra can be separated by stretches of several $100 \mathrm{~km}$ of unsuitable habitat. Long stretches of unsuitable habitat were also recognised as barriers to dispersal for the sea anemone Actinia tenebrosa along the south-east coast of Australia (Ayre et al. 1991).

Genetic structures of populations do not necessarily reflect present-day gene flow, but can reflect historical events. For example, inter-oceanic genetic differences in the starfish Linckia laevigata (Williams \& Benzie 1998) and Acanthaster planci (Benzie 1999) were explained by restrictions in gene flow between oceans due to lower sea levels during the last ice-age. Similarly, genetic distances between populations of coastal species may have evolved when there was reduced habitat availability during glacial periods and may be maintained by present-day ecological gradients and currents (Reeb \& Avise 1990).

Although only separated by about $16 \mathrm{~km}$, the 2 sample locations at the Solomon Islands were surprisingly distinct from each other. Also, the population from Solomon Island B, showed no significant genetic distance with samples from the Torres Strait located about $1500 \mathrm{~km}$ away. The significant genetic distances between the 2 Solomon Island populations and the apparent difference in connectivity with other popula- 
tions may be explained by the micro-geography of these 2 locations. The population from Solomon Island A was sampled in a lagoon system which is nearly closed to the ocean, whereas the location at Solomon Island B is open towards the ocean. It appears that the lagoonal population is genetically isolated from other populations, and that the open coastal populations on the Solomon Islands may have nearly unrestricted gene flow with populations from Torres Strait.

Along the north-east coast of Australia, genetic distances increased with geographical separation, suggesting that most of the dispersal may be explained through isolation by distance. This relationship became less distinct when samples from the Solomon Islands were included, mainly because genetic distances between those samples and those from the Torres Strait samples where relatively small given their large geographic separation.

Differences in the nature of dispersal among populations in different parts of their range, or over different spatial scales, has been described before in IndoPacific marine species. For example, Acanthaster planci showed isolation by distance within regions, but patterns were less distinct when comparisons between the Pacific and Indian Ocean were made (Benzie 1999). Similarly, Tridacna maxima in the Pacific Ocean showed isolation by distance within island chains, but patterns consistent with an island model between island chains (Benzie \& Williams 1997). In these cases, it was suggested that isolation by distance within regions represented recent dispersal and that differences between regions reflected divergence during times of lower sea level.

Uthicke \& Benzie (1999) suggested that the genetic similarity between the deep and shallow populations in Hervey Bay, in conjunction with the large body size of deep-water individuals, supports previous notions that this species settles in shallow seagrass beds and later migrates to deeper areas (Vail 1989, James et al. 1994). The population at Upstart Bay sampled 2 yr apart did not change in allele frequencies, and individuals were small on both occasions. One reason for this may be that they simply did not grow during this period. However, known growth rates for Holothuria scabra suggest that the holothurians were not older than 8 mo on both occasions (Shelley 1985, Battaglene et al. 1999). On both sampling occasions, no individual had gonads (data not shown), which suggests that they were juveniles. Therefore, it seems more likely that the population sampled at Upstart Bay consisted of recent recruits at each sampling time. Genetic similarity between the samples suggests that the populations received recruits from the same source of spawners on both occasions, and it is possible that there is a deeper population at Upstart Bay, to which individuals migrate after settlement in the shallow seagrass bed.

The identification of several separate stocks of Holothuria scabra along the north-east coast of Australia has important implications for the management of the fishery. If recruitment depends on relatively local sources, one may expect that recovery of overfished stocks is delayed depending on the magnitude of the overfishing. Therefore, it may be important that the $H$. scabra fishery in this area is managed on a local scale, and the provision of local refugia appears vital. An artificial stock enhancement using juveniles produced in hatcheries may be a viable management option (Battaglene et al. 1999). However, the genetic distinctiveness of populations, in the case of the Solomon Islands even on the scale of several kilometres, indicates that care should be taken to use only local sources of spawners for artificial stock enhancement.

Acknowledgements. We are grateful for the assistance of Ross Meaclem during the sampling in Hervey Bay. L. Peplow, S. Geier, C. Clegg, B. Schaffelke and C. Bastidas helped with sampling of other populations. We are indebted to C. Ramofafia, E. Seymore and ICLARM for collection and dissections of samples from the Solomon Islands under extreme circumstances. This study was funded in part by the Australian National Parks and Wildlife Service (Project No. WRCP-019). This is contribution No. 1070 of the Australian Institute of Marine Science.

\section{LITERATURE CITED}

Ayre DJ, Dufty S (1994) Evidence for restricted gene flow in the viviparous coral Seriatopora hystrix on Australia's Great Barrier Reef. Evolution 48:1183-1201

Ayre DJ, Read J, Wishart J (1991) Genetic subdivision within the eastern Australian population of the sea anemone Actinea tenebrosa. Mar Biol 109:379-390

Ballment E, Uthicke S, Peplow L, Benzie JAH (1997) Techniques for enzyme electrophoretic analysis of the holothurians Holothuria atra and Stichopus chloronotus (Holothuroidea: Aspidochirotida). Aust Inst Mar Sci (AIMS) Tech Rep Ser 27:1-47

Battaglene SC, Seymour JE, Ramofafia C (1999) Survival and growth of cultured juvenile sea cucumbers, Holothuria scabra. Aquaculture 178:293-322

Benzie JAH (1994) Patterns of gene flow in the Great Barrier Reef and Coral Sea. In: Beaumont A (ed) Genetics and evolution in aquatic organisms. Chapman \& Hall, London, p 67-79

Benzie JAH (1999) Major genetic differences between crownof-thorns starfish (Acanthaster planci) in the Indian and Pacific Oceans. Evolution 53:1782-1795

Benzie JAH, Stoddart JA (1992) Genetic structure of crownof-thorns starfish (Acanthaster planci) in Australia. Mar Biol 112:631-639

Benzie JAH, Williams ST (1992) No genetic differentiation of giant clam (Tridacna gigas) populations in the Great Barrier Reef. Mar Biol 113:373-377

Benzie JAH, Williams ST (1997) Genetic structure of giant clam (Tridacna maxima) populations in the West Pacific is not consistent with dispersal by present-day ocean currents. Evolution 51:768-783 
Bohonak AJ (1999) Dispersal, gene flow, and population structure. Q Rev Biol 74:21-45

Burnett WJ, Benzie JAH, Beardmore JA, Ryland JS (1995) Paterns of genetic subdivision in populations of a clonal cnidarian, Zoanthus coppingeri, from the Great Barrier Reef. Mar Biol 122:665-673

Burrage DM, Steinberg CR, Skirving WJ, Kleypas JA (1996) Mesoscale circulation features of the Great Barrier Reef region inferred from NOAA satellite imagery. Remote Sens Environ 56:21-41

Conand C (1989a) The fishery resources of Pacific island countries. Part 2: Holothurians. FAO Fish Tech Pap 272.2: $1-143$

Conand C (1989b) Les holothuries aspidochirotes du lagon de Nouvelle-Calédonie: biologie, écologie et exploitation. Etudes et thèse. ORSTOM, Paris, p 393

Conand C (1993) Reproductive biology of the holothurians from the major communities of the New Caledonian Lagoon. Mar Biol 116:439-450

Conand C (1997) Are holothurian fisheries for export sustainable? In: Lessios HA, Macintyre IG (eds) Smithsonian Tropical Research Institute, Panama. Proc 8th Int Coral Reef Symp, p 2021-2026

Conand C, Jaquemet S (2000) Overview over the last decade of sea cucumber fisheries, what means for a durable management? Tenth International Echinoderm Conference, Dunedin, New Zealand. Programme and Abstracts, p 45 (Abstract)

Doherty PJ, Planes S, Mather P (1995) Gene flow and larval distribution in seven species of fish from the Great Barrier Reef. Ecology 76:2373-2391

Harriott VJ (1980) The ecology of holothurian fauna of Heron Reef and Moreton Bay. MSc thesis, University of Queensland, Brisbane

Hedgecock D (1986) Is gene flow from pelagic larval dispersal important in the adaptation and evolution of marine invertebrates? Bull Mar Sci 39:550-564

Hochberg Y (1988) A sharper Bonferroni procedure for multiple tests of significance. Biometrika 75:800-802

James DB, Gandhi AD, Palaniswamy N, Rodrigo JX (1994) Hatchery techniques and culture of the sea-cucumber Holothuria scabra. CMFRI (Cent Mar Fish Res Inst) Spec Publ 57:1-40

Johnson MS, Threlfall TJ (1987) Fissiparity and population genetics of Coscinasterias calamaria. Mar Biol 93:517-525

Mantel N (1967) The detection of disease clustering and a generalized regression approach. Cancer Res 27:209-220

Mercier A, Battaglene SC, Hamel JF (1999) Daily burrowing cycle and feeding activity of juvenile sea cucumbers Holothuria scabra in response to environmental factors. J Exp Mar Biol Ecol 239:125-156

Mercier A, Battaglene SC, Hamel JF (2000) Settlement preferences and early migration of the tropical sea cucumber Holothuria scabra. J Exp Mar Biol Ecol 249:89-110

Nei M (1978) Estimation of average heterozygosity and genetic distance from a small number of individuals. Genetics 89:583-590

Nei M (1987) Molecular evolutionary genetics. Columbia University Press, New York

Preziosi RF, Fairbairn DJ (1992) Genetic population structure and levels of gene flow in the stream dwelling waterstrider, Aquarius (=Gerris) Remigis (Hemiptera: Gerridae). Evolution 46:430-444

Reeb CA, Avise JC (1990) A genetic discontinuity in a continuously distributed species: mitochondrial DNA in the American oyster, Crassostrea virginica. Genetics 124: $397-406$

Editorial responsibility: Otto Kinne (Editor),

Oldendorf/Luhe, Germany
Rogers JS (1972) Measures of genetic similarity and genetic distance. Stud Genet 8:145-154 (Univ Tex Publ No 7213)

Rohlf FJ (1990) NTSYS-PC: numerical taxonomy and multivariate analysis system. Exeter Software, New York

Shelley CC (1985) Growth of Actinopyga echinites and Holothuria scabra (Holothurioidea: Echinodermata) in Papua New Guinea. Proc 5th Int Coral Reef Congr 5: 297-230

Slatkin M (1993) Isolation by distance in equilibrium and nonequilibrium populations. Evolution 47:264-279

Swofford DL, Selander RB (1981) BIOSYS-1: a Fortran program for the comprehensive analysis of electrophoretic data in popuation genetics and systematics. J Hered 72: 281-283

Uthicke S (1999) Sediment bioturbation and impact of feeding activity of Holothuria (Halodeima) atra and Stichopus chloronotus, two sediment feeding holothurians, at Lizard Island, Great Barrier Reef. Bull Mar Sci 64:129-141

Uthicke S (2001) Interactions between sediment-feeders and microalgae on coral reefs: grazing losses versus production enhancement. Mar Ecol Prog Ser 210:125-138

Uthicke S, Benzie JAH (1999) Allozyme variation as a tool for bêche-de-mer fisheries management: a study on Holothuria scabra (sandfish). SPC Inf Bull Bêche-de-mer 12:18-23

Uthicke S, Benzie JAH (2000a) The effect of bêche-de-mer fishing on densities and size structure of Holothuria nobilis (Echinodermata: Holothurioidea) populations on the Great Barrier Reef. Coral Reefs 19:271-276

Uthicke S, Benzie JAH (2000b) Allozyme electrophoresis indicates high gene flow between populations of Holothuria nobilis (Holothurioidea: Aspidochirotida) on the Great Barrier Reef. Mar Biol 137:819-825

Uthicke S, Benzie JAH, Ballment E (1998) Genetic structure of fissiparous populations of Holothuria (Halodeima) atra on the Great Barrier Reef. Mar Biol 132:141-151

Uthicke S, Benzie JAH, Ballment E (1999) Population genetics of the fissiparous holothurian Stichopus chloronotus (Aspidochirotida) on the Great Barrier Reef, Australia. Coral Reefs 18:123-132

Vail L (1989) Trepang resource surveys Melville Island, Gove Harbour, Crocker Island. Department of Industries and Development and Northern Territory Fisheries

Waples RS (1987) A multispecies approach to the analysis of gene flow in marine shore fish. Evolution 41:385-400

Weir BS, Cockerham CC (1984) Estimating F-statistics for the analysis of population structure. Evolution 38:1358-1370

Wiedemeyer WL (1993) Feeding behaviour of two tropical holothurians, Holothuria (Metriatyla) scabra and H. (Halodeima) atra from Okinawa, Japan. In: Richmond RH (ed) University of Guam Press, Mangilao. Proc 7th Int Coral Reef Symp, p 853-860

Williams DM, Wolanski E, Andrews JC (1984) Transport mechanisms and the potential movement of planktonic larvae in the central Great Barrier Reef. Coral Reefs 3: 229-236

Williams ST, Benzie JAH (1993) Genetic consequences of long larval live in the starfish Linkia laevigata (Echinodermata:Asteroidea) on the Great Barrier Reef. Mar Biol 117: 71-77

Williams ST, Benzie JAH (1998) Evidence of a biogeographic break between populations of a high dispersal starfish: congruent regions within the Indo-West Pacific defined by color morphs, mtDNA, and allozyme data. Evolution 52: 87-99

Wright S (1978) Evolution and the genetics of populations. Vol 4. Variability within and among natural populations. University of Chicago Press, Hawaii, Honolulu

Submitted: August 30, 2000; Accepted: November 22, 2000 Proofs received from author(s): June 25, 2001 